\title{
Evaluation of vertebral fractures in patients presenting to emergency department with trauma
}

\author{
Acil servise başvuran travmalı hastalarda vertebra kırıklarının \\ değerlendirilmesi
}

\author{
Murat UYSAL ${ }^{1}$, Mehmet ESEN $^{2}$
}

\begin{abstract}
The aim of this study was to investigate the distribution of traumatic vertebral fractures according to their demographic features and anatomical localizations. The study included 351 patients (211 males and 140 females) who presented to emergency service with trauma. Totally 568 vertebral fractures were detected on direct radiograms and computed tomograms (CT). Among all 568 fractures, 87 were in cervical, 221 were thoracic and 260 involved lumbar spine. Fractures were most commonly localized to T12 and L1 vertebrae. Fifty-four patients had also a fracture at different bones besides vertebrae. The most frequent cause of the trauma was falls, followed by intra-, and extra-vehicular accidents (IVAs, and EVAs, respectively). According to our results, almost all of the vertebral fractures occurred due to high-energy traumas such as IVMVA, EVMVA and falls from a height. Patients presenting to emergency department because of high energy traumas should be regarded to have vertebral fractures until they are ruled out. In our opinion, CT should be used along with anteroposterior, and lateral direct vertebral radiograms to complete evaluation of the entire spinal area and not to miss vertebral body fractures.
\end{abstract}

Keywords: Vertebra, fracture, spine, computed tomography, direct radiogram, trauma

\section{öz}

Bu çalışmanın amacı, travmatik vertebra kırıklarının demografik özelliklerine ve anatomik lokalizasyonlarına göre dağılımını araştırmaktır. Çalışma travma nedeniyle acil servisine başvuran 351 hastayı (211 erkek ve 140 kadın) içermektedir. Üç yüz elli bir hastada direkt grafiler ve bilgisayarlı tomografi (BT) ile toplam 568 vertebra kırığı saptandı. Beş yüz altmış sekiz kırık arasında 87'si servikal, 221'i torakal ve 260'ı bel omurgasında yer almaktaydı. Kırıklar en yaygın olarak T12 ve L1 vertebralara lokalizeydi. Elli dört hastada vertebra dışındaki diğer kemiklerde de kırık saptandı. Travmanın en sık nedeni düşmeler idi, bunu sırasıyla araç içi motorlu araç kazası (AIMAK) ve araç dışı motorlu araç kazası (ADMAK) izledi. Sonuçlarımıza göre, vertebra kırıklarının neredeyse tamamı düşme, AiMAK ve ADMAK gibi yüksek enerjili travmalara bağlı olarak meydana gelmekteydi. Yüksek enerjili travmalar nedeniyle acil servise başvuran hastalar aksi gösterilene kadar vertebra kırığı olarak düşünülmelidir. Kanımızca, BT tüm omurganın birlikte değerlendirilebilmesi ve vertebra cisim kırıklarının atlanmaması açısından iki taraflı direkt radyografiler ile birlikte kullanılmalıdır.

Anahtar kelimeler: Vertebra, kırık, omurga, bilgisayarlı tomografi, direkt radyografi, travma

\section{INTRODUCTION}

Although vertebral fractures are observed in only a minority of patients presenting with trauma, they are serious injuries in terms of mortality and morbidity ${ }^{1,2}$. Apart from the osteoporotic fractures seen in the elderly people, vertebral fractures generally occur as a result of high energy traumas ${ }^{3}$. These fractures may have dire consequences, therefore it is best to take preventive measures before they happen ${ }^{1,4}$.
There is a marked increase in the number of vertebral fractures and spinal cord injuries that are in parallel with the increase in motor vehicle accidents and falls from a height. Although treatment of vertebral fractures is one of the most discussed topics in orthopedic surgery, time to diagnosis has been shortened with advanced imaging techniques, and it has been possible to perform early surgical interventions ${ }^{5}$. Considering patient density and limited time in the emergency departments, it is very important to evaluate patients for vertebral fractures promptly 
and make accurate diagnosis.

Radiological imaging should follow initial evaluation and physical examination ${ }^{1,6}$. When there is a suspicion of fracture after physical examination, direct radiogram is performed in the first step, and computed tomography (CT) is performed if it is necessary to examine the extent of damage. Thus, attempts have been made to protect the patients from unnecessary high dose radiation exposure during CT. However, among the patients taken into operation, additional vertebral fractures may be detected, which can be located at a different region than has been detected with direct radiogram. Therefore, many centers utilize $\mathrm{CT}$ as a first step imaging method in order to detect both multiple vertebral fractures and the accompanying pathologies. In case there are neurological findings in patients, magnetic resonance imaging (MRI) can be performed in addition to $\mathrm{CT}^{6}$. Additionally, $\mathrm{MRI}$ is a useful tool for the assessment of the integrity of the posterior ligamentous complex (PLC) of the spine following injury. Decision-making with regards to surgical intervention is often dependent on the presence of spinal stability. Therefore, the use of MRI to evaluate patients with spine injury has improved our understanding of these injuries and has started to guide the decision-making process for the treatment ${ }^{7}$.

It is very important for the physicians evaluating trauma to have knowledge about which types of vertebral fractures may be missed using direct radiograms and not to overlook other fractures and pathologies accompanying vertebral fractures. For this reason, we investigated the vertebral fractures in terms of the following features: (i) distribution of vertebral fractures according to demographic features, (ii) most frequent fracture types and their anatomical localizations, (iii) radiological evaluation results of fractures, (iv) major causes of fractures and (v) other accompanying injuries in patients who had traumatic vertebral fractures.

\section{MATERIAL and METHODS}

In this retrospectively designed study, 351 patients diagnosed with vertebral fractures who presented to the department of emergency medicine because of trauma between January 2011 and January 2017 were examined by reviewing radiological archives and patient records. AP, lateral radiograms and CT images were used in the study. Direct $X$-ray radiograms were performed in all patients for diagnostic purposes. In only four patients, CT was not performed, and diagnosis of fracture was made based on only direct radiograms in those four patients. Very few patients had neurological findings and therefore only eight patients were asked for MRI. Because of the limited number of patients who underwent MRI, we could not use the MRI findings in our study. Age, sex, trauma type and other injuries accompanying the fracture were recorded from patient records. Fractured vertebrae were determined by examination of direct radiograms and CT images. Parts of the vertebrae where the fracture was localized, including body of vertebra, pedicle of vertebral arch, lamina of vertebral arch, transverse process and spinous process were determined. Additionally, vertebral fractures were classified according to Denis classification system that includes burst fractures, compression fractures, fracture-dislocation and seatbelt (flexiondistraction) fractures (Table 1). Statistical analysis for the evaluation of the data was carried out using IBMSPSS 20.0 software. Student t test and chi-square test were used for analyses. $p<0.05$ value was accepted as being statistically significant.

Table 1. Denis classification of spinal trauma.

\begin{tabular}{ll}
\hline Fracture types & \\
\hline 1. Compression & \\
A & Involvement of both end plates \\
B & Involvement of superior end plate \\
C & Involvement inferior end plate \\
D & Both end plate intact \\
2. Burst & Fracture of both end-plates \\
A & Fracture of the superior end-plate \\
B & Fracture of the inferior end-plate \\
C & Burst rotation \\
D & Burst lateral flexion \\
E & \\
3. Seat belt & One-level injury \\
A & Two-level injury \\
B & \\
4. Fracture-dislocation & Flexion-rotation type \\
A & Flexion-distraction type \\
B & Shear type \\
C & \\
\hline
\end{tabular}




\section{RESULTS}

The study group consisted of 351 patients (211 males and 140 females; range, 18-87 years, mean age of 46 years) (Table 2). Mean age was slightly higher for males (47 years) than females (44 years) but this difference was not statistically significant $(p=0.608)$.

Table 2. Distribution of patients according to cause of fracture.

\begin{tabular}{llllll}
\hline & & \multicolumn{4}{c}{ Cause of fracture } \\
\cline { 3 - 6 } Gender & $\begin{array}{l}\text { Mean age } \\
\text { (years } \pm \text { SD) }\end{array}$ & EVMVA & IVMVA & Fall & $\begin{array}{l}\text { Gunshot } \\
\text { injury }\end{array}$ \\
\hline $\begin{array}{l}\text { Male } \\
(n=211)\end{array}$ & $47 \pm 21$ & $29(14 \%)^{*, \#}$ & $86(41 \%)$ & $91(43 \%)$ & $5(2 \%)^{*, \phi}$ \\
$\begin{array}{l}\text { Female } \\
(n=140)\end{array}$ & $44 \pm 19$ & $6(4 \%)^{\#}$ & $47(34 \%)^{\S}$ & $86(61 \%)$ & $1(1 \%)^{*}$ \\
Total & $46 \pm 20$ & 35 & 133 & 177 & 6 \\
\hline
\end{tabular}

EVMVA: Extra-vehicular motor vehicle accident, IVMVA: Intravehicular motor vehicle accident.

${ }^{*} p<0.05$, compared with female; $p<0.001$, compared with IVMVA and Fall; ${ }^{\ddagger} p<0.001$, compared with EVMVA and IVMVA; ${ }^{\varphi} p<0.01$, compared with Fall; ${ }^{\S} p<0.01$, compared with Fall.

There were mainly 3 types of causes for trauma as EVA (extra-vehicular accident), IVA (intra-vehicular accident) and falls (from a minimum height of three meters) from a height. Vertebral fractures occurred as a result of EVAs in 35 patients, IVAs in 134 patients and falls from height in 176 patients (Table 2). Number of patients in the fall group was significantly higher than EVA and IVA groups ( $p<0.001$ and $p<0.01$, respectively). In addition to these three types of trauma, vertebral fractures occurred as a result of gunshot injury in only six patients.

Totally 568 vertebral fractures were detected in 351 patients (Table 3). Among all 568 fractures, 87 were detected in cervical, 221 in thoracic and 260 in lumbar spine (Figure 1). Fractures were mostly localized to lumbar vertebrae in the fall group $(p<0.01)$ and thoracic vertebrae in IVA group $(p<0.05)$. There were multiple vertebral fractures in 123 patients. Among these patients, 25 had triple and 14 quadruple lumbar vertebral fractures. Only one patient had septet vertebral fractures involving T4, T5, T10, L2, L3, L4 and L5 (Table 4). The remaining 83 patients had se- quentially double vertebral fractures localized to the cervical, thoracic or lumbar spinal region.

Table 3. Number of patients and fractured vertebrae.

\begin{tabular}{lll}
\hline Type & Number of patients & $\begin{array}{l}\text { Number of fractured } \\
\text { vertebrae }\end{array}$ \\
\hline Cervical & $56(16 \%)$ & $87(15 \%)^{*}$ \\
Thoracic & $124(35 \%)$ & $221(39 \%)$ \\
Lumbar & $171(49 \%)$ & $260(46 \%)$ \\
Total & 351 & 568
\end{tabular}

${ }^{*} p<0.001$, compared with thoracic and lumbar.

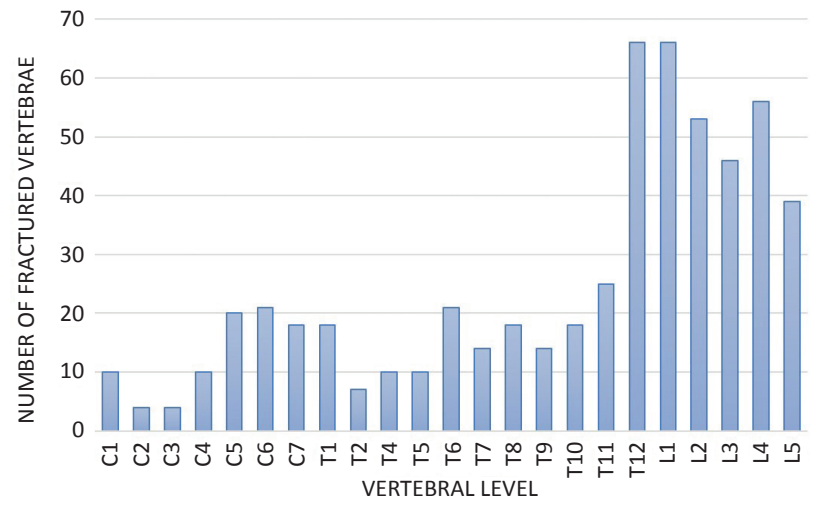

Figure 1. Distribution of fractures by vertebral level.

Table 4. Patients with three or more vertebral fractures.

\begin{tabular}{lll}
\hline Patient & $\begin{array}{l}\text { Number of fractured } \\
\text { vertebrae }\end{array}$ & Fracture level \\
\hline $1-4$ & 3 & $\mathrm{C} 4, \mathrm{C} 5, \mathrm{C} 6$ \\
5 & 3 & $\mathrm{C} 7, \mathrm{~T} 11, \mathrm{~L} 1$ \\
$6-8$ & 3 & $\mathrm{~T} 6, \mathrm{~T} 7, \mathrm{~T} 8$ \\
9 & 3 & $\mathrm{~T} 8, \mathrm{~L} 3, \mathrm{~L} 4$ \\
$10-13$ & 3 & $\mathrm{~L} 1, \mathrm{~L} 2, \mathrm{~L} 3$ \\
$14-24$ & 3 & $\mathrm{~L} 3, \mathrm{~L} 4, \mathrm{~L} 5$ \\
25 & 4 & $\mathrm{~T} 6, \mathrm{~T} 8, \mathrm{~T} 11, \mathrm{~T} 12$ \\
$26-28$ & 4 & $\mathrm{~T} 10, \mathrm{~T} 11, \mathrm{~T} 12, \mathrm{~L} 1$ \\
$29-39$ & 4 & $\mathrm{~L} 2, \mathrm{~L} 3, \mathrm{~L} 4, \mathrm{~L} 5$ \\
40 & 7 & $\mathrm{~T} 4, \mathrm{~T} 5, \mathrm{~T} 10, \mathrm{~L} 2, \mathrm{~L} 3, \mathrm{~L} 4, \mathrm{~L} 5$
\end{tabular}

Fractures were most frequently localized to the vertebral body (61\%), followed by transverse $(27 \%)$ and spinous processes $(7 \%)(p<0.001)$ (Table 5, Figure 2). Additionally, fractures were detected in more than one part in $5 \%$ of the vertebrae. Among 371 vertebral body fractures, 270 had burst, 66 compression, 21 had seat belt fractures and 14 had fracturedislocations $(p<0.001)$ (Table 6,7$)$. 
When 14 patients that did not undergo CT examination were excluded from the study, the diagnosis of fracture could be made based on direct radiograms

Table 5. Distribution of patients and vertebrae according to the fractured part of the vertebra.

\begin{tabular}{lll}
\hline Part of the vertebra & $\begin{array}{l}\text { Number of } \\
\text { patients }\end{array}$ & $\begin{array}{l}\text { Number of } \\
\text { vertebrae }\end{array}$ \\
\hline Body & 246 & 347 \\
Spinous process & 25 & $42^{*}$ \\
Transverse process & 53 & $151^{*}, \#$ \\
Body + transverse process & 23 & $24^{*, \#, \phi}$ \\
Transverse process + spinous process & 4 & $4^{*, \#, \phi, \S}$ \\
Total & 351 & 568 \\
& & \\
\hline
\end{tabular}

${ }^{*} p<0.001$, compared with Body; ${ }^{*}<<0.001$, compared with Spinous process; ${ }^{\varphi} p<0.001$, compared with Transverse process; ${ }^{s} p<0.001$, compared with Body + transverse process.

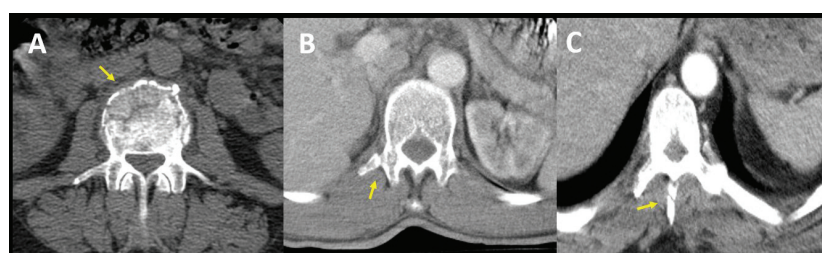

Figure 2. Computed tomography images of vertebral fractures in various patients. Arrow points at the broken vertebral body of L3 (A), transvers process of T11 (B) and spinous process of T11 vertebra (C).

Table 6. Number of fractured vertebrae according to Denis classification system.

\begin{tabular}{ll}
\hline Fracture type & Number of vertebrae \\
\hline Compression & $66^{*}$ \\
Type A & - \\
Type B & 21 \\
Type C & 6 \\
Type D & 39 \\
Burst & 270 \\
Type A & 56 \\
Type B & 190 \\
Type C & 14 \\
Type D & 4 \\
Type E & 6 \\
Seat belt & $21^{*}, \#$ \\
Type A & 21 \\
Type B & - \\
Fracture-dislocation & $14^{*}, \#$ \\
Type A & - \\
Type B & - \\
Type C & 14 \\
Total & 371 \\
\hline
\end{tabular}

${ }^{*} p<0.001$, compared with Burst; $\# p<0.001$, compared with Compression.
Table 7. Distribution of vertebral body fractures.

\begin{tabular}{lllll}
\hline & \multicolumn{4}{c}{ Fracture type } \\
\cline { 2 - 5 } Type & Compression & Burst & Seat belt & Fracture-dislocation \\
\hline Cervical & $6^{*}$ & 41 & - & $10^{*}$ \\
Thoracic & $31^{*}$ & 109 & $17^{*, \phi}$ & $4^{*, \#}$ \\
Lumbar & $29^{*}$ & 120 & $4^{*, \#}$ & - \\
Total & $66^{*}$ & 270 & $21^{*, \#}$ & $14^{*, \#}$ \\
\hline
\end{tabular}

${ }^{*} p<0.001$, compared with Burst; ${ }^{\varphi} p<0.05$, compared with Compression; $" p<0.001$, compared with Compression.

in only 172 of the remaining 337patients. Diagnosis of 165 patients was made using $\mathrm{CT}$, and fractures 133 of those 165 patients fractures were detected at vertebral bodies $(n=133)$, at transverse $(n=18)$ and spinous ( $n=14$ ) processus (Figure 3 ). When CT was regarded as gold standard, sensitivity of direct radiogram was calculated as $51 \%$.

Seventy patients had a fracture at different bones besides their vertebral fractures. There were rib fractures in 35 patients with thoracic or lumbar vertebral fractures, and there were hip bone fractures in 18 patients with lumbar vertebral fractures. The remai-

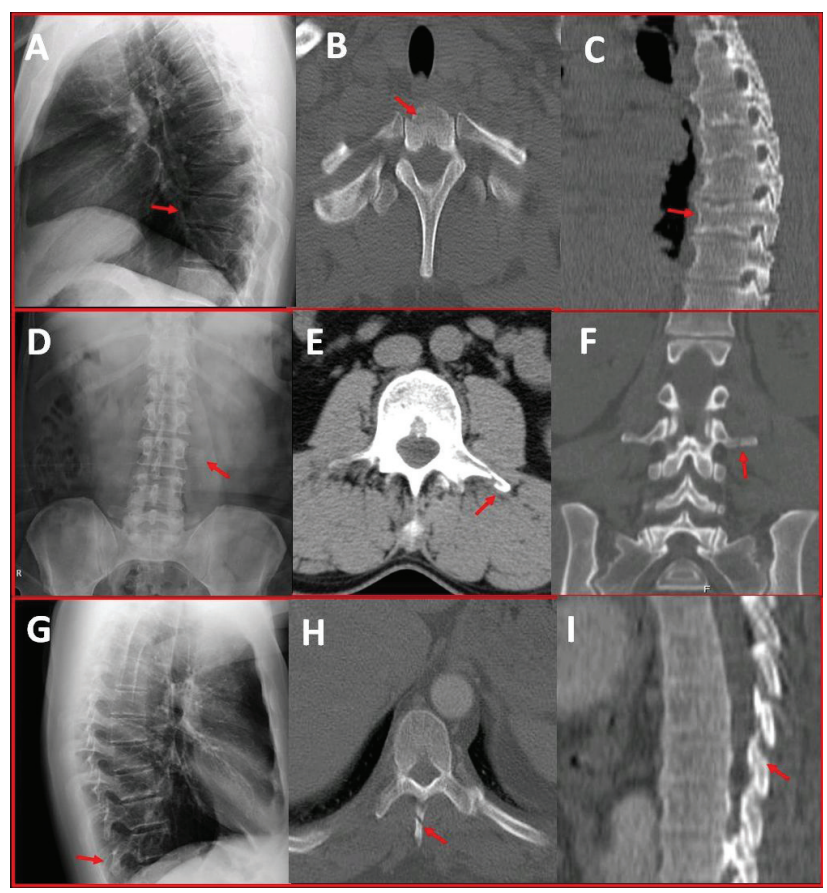

Figure 3. Images show corpus fracture, transvers process fracture and spinous process fracture detected by computed tomography but not direct radiogram in the same patients. Axial (B, E, H), sagittal (C, I) and coronal (F) CT images and direct radiograms (A, D, G) show vertebral fractures (arrow). 
ning fractures were localized to scapula, skull, clavicle, humerus, coccyx, sacrum, femur and tibia (Table 8). Other pathologies that accompanied vertebral fracture were determined as pneumothorax, hemothorax, liver laceration, intracranial hemorrhage, pulmonary contusion and retroperitoneal hemorrhage (Table 8).

Table 8. Associated injuries in patients with vertebral fracture.

\begin{tabular}{llll}
\hline $\begin{array}{l}\text { Fractured } \\
\text { bone }\end{array}$ & $\begin{array}{l}\text { Number of } \\
\text { patients }\end{array}$ & Accompanying pathology & $\begin{array}{l}\text { Number of } \\
\text { patients }\end{array}$ \\
\hline Rib & 35 & Intracranial hemorrhage & 18 \\
Hip bone & 18 & Pneumothorax & 10 \\
Skull & 18 & Pulmonary contusion & 10 \\
Sacrum & 14 & Hemothorax & 7 \\
Scapula & 7 & Retroperitoneal hemorrhage & 4 \\
Coccyx & 7 & Liver laceration & 4 \\
Clavicle & 4 & Splenic rupture & 3 \\
Humerus & 4 & & \\
Femur & 4 & & \\
Tibia & 1 & & \\
\end{tabular}

\section{DISCUSSION}

When all age groups are considered, vertebral fractures generally occur as a result of high energy traumas, whereas osteoporotic vertebral fractures are commonly observed in elderly patients ${ }^{3,8,11}$. In the study by Liu et al. ${ }^{10}$ and Erdogan et al. ${ }^{11}$ investigating traumatic vertebral fractures, patients were mostly aged between $30-50$ years (47 and 52\%, respectively), whereas in our study patients were mostly (46\%) aged between 40-60 years and approximately a quarter of the patients were over 65 years of age. Osteoporotic vertebral fractures may occur without trauma; nonetheless, our results suggest traumatic vertebral fractures are also remarkably frequent in elderly population. Previous studies have reported that vertebral fractures were observed 1.9-3.3- fold more frequent in men than in women ${ }^{2,4,10,12,13}$. Contrary to these results, we found male-to-female ratio as 1.5. Similar to our result, Roche et al. ${ }^{14}$ and Erdogan et al. ${ }^{11}$ reported male-to-female ratio as 1.6. Studies that indicated higher male to female ratios were generally carried out in countries where the contributions of women to the workforce were less than those of men (e.g. Pakistan and China). This may be the reason for the differences between studies. Therefore, low male-to-female ratio in our country may be reflecting an increase in the incidence of vertebral fractures in women as a result of their more contribution to occupational and social life today.

Falls and motor vehicle accidents are two major causes of traumatic vertebral fractures. The most important cause in developing countries is fall from tall heights. Most commonly, compression and burst fractures are observed after falls, whereas fracturedislocations are most frequently observed after motor vehicle accidents ${ }^{4,15}$. Among all causes of fractures, the incidence rates of falls have been reported to range between 54 , and $62 \%$ in various studies ${ }^{2,3,10,13,16}$. The fall from a height was observedly the most common cause of trauma at a much higher rate of $79 \%$ among patients aged over 65 years who were admitted to the emergency department ${ }^{17}$. Unlike these studies Yousefzadeh et al. ${ }^{18}$ and Karacan et al. ${ }^{19}$ said the most common cause of vertebral fractures was MVAs. In our study, the most frequent type of trauma was fall with a rate of $52 \%$. The incidence of EVA among male patients was significantly lower than that of IVA and fall. However, in female patients, falls were significantly more frequent than both EVA and IVA.

Wang et al. ${ }^{2}$ examined vertebral fractures in traumatic patients and the most frequently reported vertebral fractures were localized at L1 (24\%), T12 (15\%) and L2 (11\%), in decreasing order of frequency. Roche et al. ${ }^{14}$ and Yousefzadeh et al. ${ }^{18}$ found that the most common vertebral fractures involved T12 and L1. In our study, fractures were most frequently localized to T12 (12\%), L1 (12\%), L4 (10\%) and L2 (9\%). There is a fulcrum of increased motion at T12-L1 junction, therefore this area is more commonly affected from spine trauma. When patients were divided into three groups according to the trauma types (EVA, IVA and fall) we found lumbar vertebral fractures were most common in the EVA and fall groups. However thoracic vertebral fractures were most common in IVA group. Additionally, there was no cervical vertebra fracture in any of the patients in the EVA group. Similarly, in the study by Ustundag et al. ${ }^{20}$ involving only cervical vertebral fractures in 34 patients, EVA was the cause 
of the cervical fracture in only one patient.

The first imaging study to be performed in patients with suspect vertebral fractures is direct X-ray. In AP and lateral radiograms, alignment of vertebrae, vertebral body heights, interpedicular distances, zygapophyseal joints, spinous processes and transverse processes should be thoroughly evaluated. Another diagnostic method is computed tomography (CT) which can reveal fractures that are not detected on direct radiograms, and show that fractures that seem like compression fracture on direct radiograms are burst fractures in fact. For this reason, CT is routinely utilized in many centers to determine the type of fracture and to plan treatment. In our study, sensitivity of direct radiogram was $51 \%$, therefore diagnosis of fracture could only be made with CT that was performed after direct radiograms were obtained in $49 \%$ of the patients. Regarding the sensitivity of $\mathrm{X}$-ray radiography, previous studies have reported rates ranging from $33 \%$ to $74 \%{ }^{21-24}$. The different ratios between reports may be due to the different number of patients and vertebral fractures between studies, and it may also be stem from using various types of CT scans in these studies. In the light of the findings of our study, it is understood that transverse process or spinous process fractures compared the vertebral body fractures more easily detected by $\mathrm{X}$-ray radiography. Berry et al. ${ }^{21}$ evaluated 26 patients with thoracolumbar spine fractures and found $73 \%$ sensitivity for X-ray radiography. In their study, they found $64 \%$ of the fracture was at the transverse process that this rate is significantly higher than ours, and this situation may lead to differences between studies.

In our study, fractures were most frequently localized to the body of the vertebrae, followed by transverse and spinous processes. Among vertebral body fractures, $18 \%$ were compression, $72 \%$ were burst, $6 \%$ were seat belt fractures and only $4 \%$ of them were cases with fracture-dislocation. Contrary to our results, in the study by Erturer et al. ${ }^{13}$ including 372 patients, $57 \%$ of the fractures were compression type and $39 \%$ were burst type of fractures. With aging abrupt thinning of the posterior cortex of the vertebral body immediately medial to the base of the pedicle occurs. This change in cortical thickness may be abrupt enough to cause concentration of stress at this site, which suggestively explains the reason why burst-type fractures are frequently observed ${ }^{25}$. In this consideration burst fractures may be determined at a higher rate in our study, due to the higher mean age of our patients.

Since vertebral fractures generally occur as a result of high energy traumas, there is high risk for accompanying injuries, which has been reported in the rates of $43-78 \%$, and include skeletal traumas and various organ injuries ${ }^{26,27}$. Erturer et al. ${ }^{13}$ reported that $10 \%$ of the patients had accompanying organ injuries, whereas this rate was found as slightly higher in our study (15\%). Due to the increase in morbidity and mortality, additional organ injuries in high-energy vertebral fractures should be kept in mind ${ }^{25}$.

This study has some limitations. Firstly, it included patients who were examined by radiograms and CT images. Absence of MRI findings is the main limitation of our study. Denis classification system was based on data from radiograms and computed tomograms (CTs). Although easily reproduced and well accepted in many centers, it does not adequately guide for surgical decision. Decision-making with regards to surgical intervention is often dependent on the presence of spinal stability ${ }^{28}$. The posterior ligamentous complex (PLC) is believed to be one of the primary soft-tissue stabilizers of the spine. MRI allows direct assessment of the integrity of the PLC in the setting of acute trauma ${ }^{7}$. Therefore, the use of MRI to evaluate patients with spinal trauma has great importance for the surgical decision-making process.

In conclusion, patients presenting to emergency departments because of high energy traumas should be regarded to have vertebral fractures until they are ruled out. Considering that vertebral fractures could not be detected using direct radiograms alone in almost half our patients, we believe that CT is necessary for diagnosis in suspected patients along with the routine two-sided direct vertebral radiograms. It should not be forgotten that vertebral fractures may be present at other non-neighboring levels, and the 
whole spinal area should be thoroughly evaluated. In addition, to clarify differences in vertebral fractures among years in the same country, future studies should be designed periodically and collect data in order to provide valid comparative data.

Acknowledgement: We thank Hilal Irmak Sapmaz, Ayse Duhan Tas, Tufan Alatlı, Kürşad Aytekin and Murat Zümrüt for their contribution to the study.

\section{REFERENCES}

1. NiGupta MC, Benson DR, Keenan TL. Initial evaluation and emergency treatment of the spine-injured patient. In: SkeletalTrauma: Basic Science, Management and Reconstruction. Browner BD, Levine AM, Jupiter JB, Trafton PG (eds). Saunders, Philadelphia, 2003: 685-707.

2. Wang $H$, Zhang $Y$, Xiang $Q$, et al. Epidemiology of traumatic spinal fractures: experience from medical university-affiliated hospitals in Chongqing, China, 2001-2010. J Neurosurg Spine 2012;17(5):459-468.

https://doi.org/10.3171/2012.8.SPINE111003

3. Hebert JS, Burnham RS. The effect of polytrauma in persons with traumatic spine injury. A prospective database of spine fractures. Spine 2000;25(1):55-60.

https://doi.org/10.1097/00007632-200001010-00011

4. Qureshi MA, Khalique AB, Pasha IF, et al. Epidemiology of non-disaster spinal injuries at a spine unit. J Coll Physicians Surg Pak 2010;20(10):667-670.

5. Yılmaz G, Acaroğlu E. Thoracolumbar spıne trauma. J Surg Med Sci 2006;2:5-10.

6. Arlet V, Orndorff DG, Jagannathan J, et al. Reverse and pseudoreverse cortical sign in thoracolumbar burst fracture: radiologic description and distinction--a propos of three cases. Eur Spine J 2009;18(2):282-287. https://doi.org/10.1007/s00586-008-0848-x

7. Rihn JA, Fisher C, Harrop J, et al. Assessment of the posterior ligamentous complex following acute cervical spine trauma. J Bone Joint Surg Am 2010;9 2(3):583-589.

8. Chen P, Miller PD, Binkley NC, et al. Use of lowest single lumbar spine vertebra bone mineral density T-score and other T-score approaches for diagnosing osteoporosis and relationships with vertebral fracture status. J Clin Densitom 2008;11(4):525-531. https://doi.org/10.1016/j.jocd.2008.04.009

9. Kanatli U, Ataoglu B, Ozer M, et al. Kyphoplasty for Intractable Pain Due to Glucocorticosteroid-induced Osteoporotic Vertebra Fracture of a 9-Year-Old Patient With Systemic Lupus Erythematosus: 8-Year Follow-up. J Pediatr Orthop 2014;35(6):e55-59. https://doi.org/10.1097/BPO.0000000000000346

10. Liu P, Yao Y, Liu MY, et al. Spinal trauma in mainland China from 2001 to 2007: an epidemiological study based on a nationwide database. Spine 2012;37(15):1310-1315. https://doi.org/10.1097/BRS.0b013e3182474d8b

11. Erdoğan MO, Anlas Demir S, Kosargelir M, et al. Local differences in the epidemiology of traumatic spinal injuries. Ulus Travma Acil Cerrahi Derg 2013;19(1):49-52. https://doi.org/10.5505/tjtes.2013.74501

12. Tee JW, Chan $\mathrm{CH}$, Fitzgerald MC, et al. Epidemiological trends of spine trauma: an Australian level 1 trauma centre study. Global Spine J 2014;3(2):75-84. https://doi.org/10.1055/s-0033-1337124

13. Erturer E, Tezer M, Ozturk I, et al. Evaluation of vertebral fractures and associated injuries in adults. Acta Orthop Traumatol Turc 2005;39(5):387-390.

14. Roche SJ, Sloane PA, McCabe JP. Epidemiology of spine trauma in an Irish regional trauma unit: a 4-year study. Injury 2008;39(4):436-442. https://doi.org/10.1016/j.injury.2007.12.012

15. Ho M, Hardin E. Burst fracture of the first lumbar vertebra. J Emerg Med 1999;17(5):901-902.

16. Akdemir HU, Aygun D, Katı C, et al. Three-year experience in the Emergency Department: the approach to patients with spinal trauma and their prognosis. Ulus Travma Acil Cerrahi Derg 2013;19(5):441-448. https://doi.org/10.5505/tjtes.2013.21456

17. Kara H, Bayir A, Ak A, et al. Trauma in elderly patients evaluated in a hospital emergency department in Konya, Turkey: a retrospective study. Clin Interv Aging 2014;9:17-21.

18. Yousefzadeh Chabok S, Safaee M, Alizadeh A,et al. Epidemiology of traumatic spinal injury: a descriptive study. Acta Med Iran 2010;48(5):308-311.

19. Karacan I, Koyuncu H, Pekel O, et al. Traumatic spinal cord injuries in Turkey: a nation-wide epidemiological study. Spinal Cord 2000;38(11):697-701.

https://doi.org/10.1038/sj.sc.3101064

20. Ustundag M, Orak M, Guloglu C, et al. Retrospectıve evaluatıon of cervical spıne Injury victıms presented to emergency department. JAEM 2007;6(4):18-21.

21. Berry GE, Adams S, Harris MB, et al. Are plain radiographs of the spine necessary during evaluation after blunt trauma? Accuracy of screening torso computed tomography in thoracic/lumbar spine fracture diagnosis. J Trauma 2005;59(6):1410-1413. https://doi.org/10.1097/01.ta.0000197279.97113.0e

22. Gestring ML, Gracias VH, Feliciano MA, et al. Evaluation of the lower spine after blunt trauma using abdominal computed tomographic scanning supplemented with lateral scanograms. Journal of Trauma-Injury Infection and Critical Care 2002;53(1):9-14. https://doi.org/10.1097/00005373-200207000-00003

23. Sheridan R, Peralta R, Rhea J, et al. Reformatted visceral protocol helical computed tomographic scanning allows conventional radiographs of the thoracic and lumbar spine to be eliminated in the evaluation of blunt trauma patients. J Trauma 2003;55(4):665-669. https://doi.org/10.1097/01.TA.0000048094.38625.B5

24. Wintermark M, Mouhsine E, Theumann N, et al. Thoracolumbar spine fractures in patients who have sustained severe trauma: Depiction with multi-detector row CT. Radiology 2003;227(3):681-689.

https://doi.org/10.1148/radiol.2273020592

25. Heggeness MH, Doherty BJ. The trabecular anatomy of thoracolumbar vertebrae: implications for burst fractures. J Anat 1997;191:309-312. https://doi.org/10.1046/j.1469-7580.1997.19120309.x

26. Fan RS, Schenk RS, Lee CK. Burst fracture of the fifth lumbar vertebra in combination with a pelvic ring injury. J Orthop Trauma 1995;9(4):345-349. https://doi.org/10.1097/00005131-199509040-00013

27. Korovessis PG, Stamatakis M, Baikousis A. Unrecognized laceration of main bronchus caused by fracture of the T6 vertebra. Eur Spine J 1998;7(1):72-75. https://doi.org/10.1007/s005860050032

28. Vaccaro AR, Rihn JA, Saravanja D, et al. Injury of the posterior ligamentous complex of the thoracolumbar spine: a prospective evaluation of the diagnostic accuracy of magnetic resonance imaging. Spine 2009;34(23):E841-7. https://doi.org/10.1097/BRS.0b013e3181bd11be 